all the hardship which the law might otherwise cause the land owner in special cases and make the law less vulnerable before the courts. In both these respects a board of appeals would in this connection render a service analogous to that which it has so admirably performed under zoning laws.

Illustrations of the service which a board of appeals could render in the administration of this provision of the planning law are numerous and varied; and of these jllustrations I will cite three.

If a land owner desires to erect a brick structure in the bed of a mapped street, the board of appeals could offer to authorize a wooden building, pointing out that such a building could be amortized in a given number of years, with a fair return to the land owner on the value of his land. No court would hold that (in the absence of other complications) the land owner was rightly aggrieved to whom such an offer was made, even if he could obtain a larger amount by violating the city plan, contrary to the general interest; for if the return is a fair one he is not unjustly deprived of his property.

If a building were proposed a part of which only would project into the future street, the board of appeals could offer to consent to a building of which the projecting portion was only one story high; backing up the proposal by plans showing the suitability and yield of such a building in such a location.

If the city intended to build the street within, perhaps, five years, the board could be authorized, with the consent of some proper city authority, to agree with the land owner that the city would build it within that time. This agreement would usually make it certain that the location of the building with relation to the future street, so soon to be built, was the most profitable one, especially if the building was to be an expensive one.

A provision making a few of the essential features of the city plan binding upon the land planned is essential to the success of city planning in this country. The provision here suggested would seem to accomplish everything which is secured by the provisions for the same purpose of foreign laws, by methods already familiar in this country, and therefore more likely to win the approval not only of city planners, but of our courts.

\title{
THE BUILDING GUILDS OF ENGLAND
}

\author{
BY CHARLES HARRIS WHITAKER \\ Editor, Journal of American Institute of Architects
}

BEnIND the building guilds of England there lies a background that reaches far back into history,-to the time of Asoka, for example (300 B. C.), when the sacred guilds of India were not only the revered guardians of the traditions of craftsmanship, but when their members were the chosen interpreters, through the symbolism of architecture, of the religion of the people. Of more modern days, and better known generally, were the medieval guilds, where craftsmanship and the honor of a vocation were honored above gain. The rise and decline of the medieval guilds might very profitably be studied in these days, for there is much in the present 
situation that resembles their history. Especially might they be studied by those ardent advocates of art, who in their ardor seem to have forgotten the relationship of free workmen to the exercise of the creative impulse.

In England, for some years, the National Guilds League has been building a new concept of vocational or functional organization, as opposed to the present system of organization by crafts or trades. Its premises are based upon the eventual actual organization of all industry on guild lines. Those who work in any industry, whether with hand or brain, are to direct and control that industry. The whole guild system is further predicated upon a new theory of economics and a new political concept of the state. Those who are curious in the matter may find ample literature on the subject. ${ }^{1}$

\section{THE BUILDING TRADES PARLIAMENT}

Just before the war, the building industry in England was on the verge of a bitter struggle. Its long history of lockout and strike, of contention and quarrel, was about to culminate in a national grapple between the two forces. With the outbreak of the war, a truce was declared, and it was then that the more far-seeing men in the industry began to cast about for a basis on which the industry might be efficiently revived after the war. This led to the formation of the Building Trades Parliament, composed of an equal number of delegates from the

${ }^{1}$ Guild Socialism, by G. D. H. Cole. F. A. Stokes Co., N. Y. Proposed Roads to Freedom, by Bertrand Russell. F. A. Stokes Co., N. Y. Guild Principles in War and Peace, by S. G. Hobson. Old Worlds for New, by A. J. Penty. The Meaning of National Guilds, by Reckit and Bechoffer. Guilds and the Social Crisis, by A. J. Penty. See also the Journal of the American Institute of Architects, 1919-1921. employers' and the employes' organizations. As both sides are highly organized in England, the parliament is a very representative body. In 1916, it appointed a committee, among others, on scientific management and reduction of costs, charging it with the tasks suggested in its title. In August, 1919, the committee handed in its report, which has remained as one of the most striking contributions to the studies of industry that have resulted from our post-war difficulties.

The striking character of the report was greatly emphasized by the fact that the committee whence it emanated was composed of eight employers and eight employes. These sixteen men sat down together not primarily to see what could be done to meet an emergency, for the war had still kept government control intact, but to find out what was the matter. They began sensibly. Generally the prescription precedes the analysis instead of following the diagnosis. The report they presented was therefore not a partial pronouncement, or a piece of special pleading.

In substance the committee found that "unemployment" was the curse of the building industry, but in its conclusions for dealing with this primary difficulty, it found itself obliged to recommend that the building industry of England be transformed into a public service. It suggested the method by which this could be accomplished, and laid down certain principles for dealing with both employer and employe. But the essentials of the report correspond very closely with the guilds concept, and no doubt the report helped a good deal in the final emergence of the building guilds. The first one was incorporated in Manchester, some months after the report mentioned. It was promoted by the bricklayers of that city, and the 
secretary chosen was Mr. S. G. Hobson, one of the recognized leaders in the guilds movement. So swiftly did the idea spread, that the Manchester Guild found no difficulty in enlisting the active co-operation of all the trades represented in building, and it then made a bid to the corporation of Manchester for the erection of some 200 houses.

\section{THE GOVERNMENT NOT SYMPATHETIC}

It has been but natural that the building guilds movement so far has centered about the erection of houses. Likewise it is also true that the demand for houses and the complete failure of the old contract system, largely speculative as it is, to produce houses, helped the guildsmen in winning interest and popular approval for their venture. But as all house building is now practically under government control in England, the guilds were obliged to have their contracts approved by the Ministry of Health, the department having jurisdiction. There they encountered a long and trying delay. The guild's proposals were novel, and they were distinctly upsetting to men who believed that the only way to build was under the old contract method. The guilds' bids were based in the first place upon the union rate of wages and continuous pay to all workers. In the second place, there were to be no profits. A certain percentage was to be paid on the cost of the work, out of which to pay for plant required, and unemployment. The government, after delaying the acceptance of the guilds' bids for many months,-bids involving some millions of pounds and approved by the municipal authorities involved,-finally agreed to sanction twenty contracts. But the pressure of the old employers' group, inserted almost from the start, was continually increasing, and it was only by dint of the hardest kind of work that the twenty contracts were finally passed by the Ministry of Health. As the work progressed, resistance increased. It was plain that the guilds were going to show a record for building costs such as would confirm their theories. And this proved quite true. The figures for building the first houses, under the guilds, at Bentley, in Yorkshire, show that they have been able to build a house for $£ 200$ less than similar houses built under the old contract system at the same place. Probably a hundred contracts would be signed now, with the guilds, by municipalities all over England, were it not for the embargo that the Ministry of Health has laid upon this method. Those who wish to see the guilds have a fair trial,--and it seems incredible that any sensible person could wish for less,-find the action of the Ministry of Health to be not only stupid, but sinister, since it offers abundant proof, as the guildsmen contend, that the whole opposition of the ministry is based upon the "pull" exerted politically by the building employers' organizations.

\section{THE GUILDS AT WORK}

At the same time, the guilds are working out their twenty contracts. There seems every reason to believe that the completion of others, following upon that of Bentley (where the figures are certified by the authorities), will indicate that the guilds can build not only as well, or better, than under the old contract system, but also cheaper. If this is true, what ought to be the answer?

The failure of the employing group to understand the human concept of the guildsmen is plainly evidenced in their method of argument. They upbraid the bricklayers, for example, who lay about twice as many bricks per day 
on guild work as on contract work. But the answer is that under the guilds system the bricklayer is not interested in sabotage, the obstructive method universally employed in all industry to-day as a means of holding up prices. The guildsman is literally "on his own"; he is not working for a contractor's profit; he has a voice in the government of his industry; he is not chafing and worrying over the specter of unemployment, for the guild pays him on rainy days when he cannot work. It is part of the guild concept that each industry should provide for any unemployment, and that no industry should be able to throw its workers, when not needed, back on the community. In other words, the old theory of a reservoir of unemployment, to be emptied and filled at the will of the employer, is contrary to the guildsman's concept of industry. Ought it not to be contrary to the theory of any system of conducting industry, when one stops to think of it?

\section{THE GUILD IDEA}

Taking the affirmative, one naturally finds oneself confronted with a variety of problems. Their very complexity seems to render them almost baffling, for they invite attention to a whole new theory of industrial organization, - the one based primarily upon the theory that there is work enough for all and that industry ought to be organized for that purpose, and not, as at present, around the competitive price system. A guildsman would point out what is becoming very plain to impartial observers, that industry to-day is of necessity controlled not by the technical factors involved,-not by the theory of producing the greatest possible quantity of any given product in order that all may have enough,-but by the financial demands which are predicated upon profit, and which insist that we shall not have abundance and low prices, but that we must have scarcity in order to have high prices. Farmers burning their cotton, or their wheat, factories shutting down to "improve the tone of the market," raw materials pooled in order to hold them out of the market until the price can be raised, food products warehoused and stored for the one purpose of raising prices, trades union leaders holding up work as a means of extorting bribes, workmen reducing their output as a means of keeping themselves in work, lenders of money demanding bonuses for housing loans,all of these practices commonly known and universally sanctioned are in reality nothing but systematic obstructions introduced into the stream of production flow in order to dam it up for the purpose of raising prices. Never, and that must be thoroughly understood, for the purpose of increasing the production flow, although there is not a moment when the whole flow of production could not be absorbed by a happy people if it were not for the financial factors which stand as a barrier to its distribution and consumption. Hence, what is commonly called "overproduction" is in reality nothing more than "underconsumption."

The guildsmen of England see industry as something of vital concern, into the functioning of which financial factors ought not to be allowed to intrude and obstruct the flow. Their theory of "not working for a profit" has caused a good deal of discussion. Naturally it is bound to. But an acceptance of that theory, after it is well understood, is basic if one is to follow the whole theory of guilds organization. But "no profit" does not mean "no pay," nor does it mean one level of pay for all work. It means a fair pay for the work performed, 
whether of hand or of brain, and it means a system of self-governing industry in which all who participate shall have a voice in fixing remuneration, the terms of apprenticeship, conditions of work, and above all, and perbaps beyond all, the quality of work done. (Naturally this broad control involves the rights of the consumer and his protection against unfair wages, but that is provided for in the guilds program.)

The guilds do not revolve about material factors alone. Predicated as they are upon theories quite contrary to those that now govern and control the operation of industry, does not mean that the guilds are purely a material affair. To restore the creative impulse to industry is quite as much their purpose as to effect production and distribution such as will insure abundance instead of searcity. This is certainly one of the reasons why the building guilds have spread, like wildfire, throughout England. The workers under the guilds system are indeed restored to their heritage of craftsmanship. It is the guild which dictates the quality of work to be done and not the financial factors involved. Certainly nothing could be more for the betterment of human shelter, no matter what its kind, than an improvement in quality of work done. Resentment at the quality of work compelled under the competitive contract system in building is a far greater factor in that malady so glibly denominated "industrial unrest," than is commonly reckoned.

\section{THEY ARE BUILDING HOUSES}

The building guilds of England have contracted for some millions of hous- ing. That which has so far been completed has passed all tests of quality, and has shown a great saving in cost. Such an experiment, based upon the principle of self-government, of fulltime pay (and that is a tremendous factor, the importance of which is too often forgotten in the consideration of many so-called "wage problems"), of no contingent profit, but a wage based on the prevailing union schedule, of the functional organization of all who build, from architect to hodcarrier, cannot but demand an impartial and conscientious scrutiny from whosoever has the intelligence to see below the surface of the present industrial tangle. Whether the building guilds of England shall survive is a question that no man may answer at this moment. If their successes continue, it seems difficult to believe that the English people will prefer to pay more for their buildings by reverting to the method which has so far failed so signally, either to produce good building cheaply or to satisfy either the material or the spiritual needs of those upon whom the building industry depends.

Even those who admire the spirit of the guildsmen, and are themselves concerned with the problems of our industrial system, often express doubts as to whether the guilds' appeal will serve to hold the movement together. Can a rational society be evolved through the guilds? Who knows? Much will evidently depend upon the degree of fair play that is extended to the building guilds, for they are an actuality, not a theory, and they have really built some hundreds of houses, will ultimately build many hundreds more, and they are now organizing to enter the field of private building of all kinds. 